\title{
Plasma protein regulation by thyroid hormone
}

\author{
K-H Lin, H-Y Lee, C-H Shih, C-C Yen, S-L Chen, R-C Yang ${ }^{1}$ and \\ C-S Wang ${ }^{2}$ \\ Department of Biochemistry, Chang-Gung University, Taoyuan, Taiwan, Republic of China \\ ${ }^{1}$ Chinese Herbal Pharmacy, Chang Gung Memorial Hospital, Taoyuan, Taiwan, Republic of China \\ ${ }^{2}$ Department of Surgery, Chang-Gung University, Taoyuan, Taiwan, Republic of China \\ (Requests for offprints should be addressed to K-H Lin; Email: khlin@mail.cgu.edu.tw)
}

\begin{abstract}
Thyroid hormones (THs) regulate growth, development, differentiation and metabolic processes by interacting and activating thyroid hormone receptors (TRs). Although much progress has been made in our understanding of the transcriptional regulation of many TR target genes, little is known of the regulation of plasma protein gene expression by TRs. To investigate the role of TRs in plasma protein expression we used human hepatocellular carcinoma cell lines and carried out cDNA microarray analysis. Our results indicate that several plasma proteins including transferrin, prothrombin, angiotensinogen, haptoglobin, $\alpha$-2-HS-glycoprotein $\alpha$ and $\beta$ chain, complement, lipoproteins and fibrinogen are up-regulated by THs. Furthermore, clusterin, $\alpha-2$-macroglobulin precursor, prothymosin $\alpha$ and $\alpha$-fetoprotein were found to be down-regulated by THs.
\end{abstract}

Transferrin, an iron-binding protein expressed in all mammals, and mainly synthesized in the liver, was investigated further. Immunoblot and Northern blot analyses revealed that exposure of HepG2-TR $\alpha 1$ sub-lines and HepG2-Neo cells to tri-iodothyronine $\left(T_{3}\right)$ induced time- and dose-dependent increases in the abundance of transferrin mRNA and protein, with the extent of these effects correlating with the level of expression of TR $\alpha 1$. Nuclear run-on experiments indicate that this induction is functioning at the transcriptional level. Moreover, cyclohexamide treatment did not eliminate the induction of transferrin by TH. Thus, our results suggest that the induction of transferrin by $\mathrm{TH}$ is direct and may in fact be mediated by an as yet unidentified response element in the promoter region.

Journal of Endocrinology (2003) 179, 367-377

\section{Introduction}

Thyroid hormones (THs) regulate growth, development, differentiation and metabolic processes by interacting with TH receptors (TRs) that bind to specific DNA sequences in the regulatory regions of target genes (Cheng 2000). TRs are members of the steroid hormone and retinoic acid superfamily of ligand-dependent transcription factors. Two TR genes, TR $\alpha$ and TR $\beta$, have been identified and located to human chromosomes 17 and 3 , respectively (Lazar 1993). Each gene encodes at least two TR isoforms (TR $\alpha 1$ and 2, and TR $\beta 1$ and 2) that are generated as a result of alternative splicing and promoter choice (Lazar 1993, Wood et al. 1996).

Much progress has been made over the past few decades in our understanding of the transcriptional regulation of TR target genes but little is known about the role of TRs in plasma protein regulation (Lazar 1993, Cheng 2000, Zhang \& Lazar 2000, Lin et al. 2001, 2002). Previously, we examined the expression of TR $\alpha 1$ and TR $\beta 1$ in nine hepatoma cell lines to investigate the role of TRs during carcinogenesis. We showed that endogenous TR $\beta 1$ is abundant in Mahlavu, SK-Hep-1 and HA22T cells, present in moderate amounts in $\mathrm{J} 5, \mathrm{~J} 7$ and $\mathrm{J} 3-28$ cells, and expressed at low concentrations in HepG2, Hep3B and PLC/PRF/5 cells (Lin et al. 1994). We also demonstrated that the abundance of the Nm23-H1 protein in these cells is inversely correlated with that of TR $\beta 1$ (Lin et al. 1995).

A major site of plasma protein production is the hepatocyte, and various in vitro techniques have been used to modulate the production of these essential proteins. For example, Chang et al. (1983) reported the establishment of a new human hepatoma cell line, HA22T/VGH. This cell line had many of the properties of human hepatocellular carcinoma. Of particular interest, only five of the 15 plasma proteins investigated were detected in the medium of HA22T/VGH cells cultured for 10 days. However, when these cells and a clonal derivative, C5, were cultured in an aggregated form, all 15 plasma proteins were present in the culture medium.

HepG2, a well-differentiated hepatocellular carcinoma cell line, secretes all 15 plasma proteins. However, the relationship between TR $\alpha 1$ and plasma proteins expression remained undetermined due to the lack of cell lines 
expressing TR $\alpha 1$ at a high level (Lin et al. 1996). Our data demonstrated (Lin et al. 1997) that the hepatoma cell line HepG2 stably expressed functional TR $\alpha 1$ and the presence of TR interacting cell-type specific factors. We are also investigating the regulation of TR target genes in the HepG2 stably expressed functional TR $\beta 1$ in other studies. Thus, using HepG2 cell lines could serve as a model system to study the cell type-specific and TR isoformspecific regulation of the tri-iodothyronine $\left(\mathrm{T}_{3}\right)$ target genes in liver. Therefore, in the present study we used isogenic cell lines derived from HepG2 that stably express high levels of wild-type TR $\alpha 1$ (HepG2-TR $\alpha 1$ cells).

Transferrin (Tf) is an essential mammalian plasma protein largely synthesized in the liver and then secreted into the bloodstream. Tf is a monomeric $80 \mathrm{kDa}$ glycoprotein consisting of a polypeptide chain of 679 amino acids and two N-linked complex type glycan chains. The Tf molecule comprises two homologous domains, the $\mathrm{N}$-terminal and C-terminal domains, each containing one iron-binding site (Kwok \& Richardson 2002). The carbohydrate moiety is attached to the $\mathrm{C}$-terminal domain. Together with ferritin, the iron-storage protein, and the $\mathrm{Tf}$ receptor, Tf is involved in maintaining iron homeostasis (Feelders et al. 1999). Tf circulates at $\sim 2$ to $\sim 4 \mathrm{mg} / \mathrm{ml}$ in the blood, where its major function is to transfer iron between sites of absorption, storage and utilization throughout the organism. Iron is essential for cell proliferation, differentiation and metabolism (Feelders et al. 1999). Interestingly, $\mathrm{Tf}$ can also act as a growth factor for a variety of cells (Theisen et al. 1993).

The mechanisms of how TR $\alpha 1$ selectively maintain liver-specific gene transcription have not yet been elucidated. To investigate this phenomenon we utilized cDNA arrays to follow the modulation of plasma protein levels in isogenic hepatocellular carcinoma cell lines when treated with TH. Furthermore, the use of cells overexpressing TR $\alpha 1$ enabled us to investigate the effect of various receptor levels on the regulation of plasma protein levels. In particular, we were interested in elucidating how THs affected iron uptake. Therefore, we further studied the effect or regulation of Tf by THs. The other up-regulated plasma proteins are also under investigation in separate studies.

\section{Materials and Methods}

\section{Cell culture}

The human hepatoma cell line HepG2 was obtained from The American Type Culture Collection and was routinely grown in Dulbecco's Modified Eagle's Medium (DMEM) supplemented with $10 \%(\mathrm{v} / \mathrm{v})$ fetal bovine serum. The TR $\alpha 1$ over-expressing cell line, HepG2-TR $\alpha 1$, has been described previously (Lin et al. 2000). In this study, three HepG2-TR $\alpha 1$-overexpressed clones (\#1-3) were used. The serum was depleted of $\mathrm{T}_{3}(\mathrm{Td})$ as described previously
(Samuels et al. 1979). Cells were cultured at $37^{\circ} \mathrm{C}$ in a humidified atmosphere of $95 \%$ air and $5 \% \mathrm{CO}_{2}$.

\section{$R N A$ preparation and labeling}

Total RNA from HepG2-TR $\alpha 1 \# 1$, \#2 and \#3 with or without $\mathrm{T}_{3}$ treatment was prepared using TRIzol (Life Technologies, Rockville, MD, USA). To fluorescently label cDNA, $30 \mu \mathrm{g}$ of total RNA from untreated cells and $50 \mu \mathrm{g}$ of total RNA from treated cells were reverse-transcribed in the presence of Cy3-dUTP and Cy5-dUTP (Amersham Inc., Piscataway, NJ, USA) respectively. Labeled cDNAs were purified and re-suspended in hybridization buffer as described previously (Eisen \& Brown 1999). The data were obtained from three independent experiments.

\section{High-sensitivity $\mathrm{cDNA}$ arrays to investigate plasma protein gene expression}

Pre-spotted cDNA microarrays, Human UniversoChip 8K cDNA arrays (Asia Biolnnovations Corporation, Taipei, Taiwan), containing 7597 genes, were used to investigate the effect of $\mathrm{T}_{3}$ on the expression of plasma proteins.

\section{Image and data analysis}

Labeled cDNAs were hybridized to the arrays overnight at $70{ }^{\circ} \mathrm{C}$. The arrays were washed as described previously (Eisen \& Brown 1999). Hybridized slides were scanned using the GenePix 4000B scanner (Axon Instrument, Atlanta, CA, USA) and images were processed using the GenePix Pro 3.0 (Axon Instrument). Microarray data were analyzed using eGenomix V1.0 (Asia BioInnovations Corporation) and Excel (Microsoft, Seattle, WA, USA).

\section{Immunoblot analysis}

Cell lysates were fractionated by SDS-PAGE on a $10 \%$ gel, and the separated proteins were transferred to a nitrocellulose membrane (Amersham). The membrane was gently shaken for $2 \mathrm{~h}$ at room temperature in 5\% $(\mathrm{w} / \mathrm{v})$ nonfat dried milk in Tris-buffered saline (TBS), washed three times with TBS, and then incubated for $1 \mathrm{~h}$ with rabbit polyclonal antibodies to Tf (1:1000 dilution in TBS) (Santa Cruz Biotechnology, Santa Cruz, CA, USA) or with mouse monoclonal antibody C4 to TR $\alpha 1$ (1:1000 dilution in TBS) (kindly provided by S.-Y. Cheng, NCI, Bethesda, MD, USA). After further washing, the membrane was incubated for $1 \mathrm{~h}$ with horseradish peroxidase conjugated to affinity-purified antibodies to either rabbit (1:2000 dilution in TBS) or mouse (1:2000 dilution in TBS) immunoglobulin (Santa Cruz Biotechnology). Immune complexes were then visualized by chemiluminescence with an ECL detection kit (Amersham). 
The intensities of immunoreactive bands were quantitated by analysis with Image Gauge software (Fuji Film, Tokyo, Japan).

\section{Determination of the trans-activation activity of TRs}

$\mathrm{T}_{3}$-dependent trans-activity of TRs was assayed in the various HepG2 cell lines as described previously (Lin et al. 1996). Briefly, cells were transfected with a luciferase reporter plasmid $(2 \mu \mathrm{g})$ containing Lys-TRE (a chicken lysozyme gene and consisting of two inverted repeats of the half-site binding motif separated by six nucleotides; thyroid hormone response element), along with a $\beta$-galactosidase plasmid $(1 \mu \mathrm{g})$ to control for transfection efficiency. Transfected cells were subsequently incubated for $24 \mathrm{~h}$ in $\mathrm{Td}$ medium containing various concentrations of $\mathrm{T}_{3}$ (Sigma, St Louis, MO, USA), after which the activities of luciferase and $\beta$-galactosidase in cell lysates were measured (Flores-Morales et al. 2002). The activity of luciferase was normalized against $\beta$-galactosidase activity.

\section{Northern blot analysis}

Total RNA was extracted from cells with the use of TRIzol reagent, and equal amounts of total RNA $(20 \mu \mathrm{g})$ were analyzed on a 1.2\% agarose-formaldehyde gel as described previously (Lin et al. 2002). This was then blotted onto a nitrocellulose membrane and subjected to Northern blot analysis as described previously (Lin et al. 2000). A full-length Tf cDNA fragment was amplified and labeled with $\left[\alpha-{ }^{32} \mathrm{P}\right] \mathrm{dCTP}(3000 \mathrm{Ci} / \mathrm{mmol}$; Amersham) by the polymerase chain reaction and used as a probe. The membrane was subsequently re-probed with a ${ }^{32} \mathrm{P}$-labeled glyceraldehyde-3-phosphate dehydrogenase (GAPDH) cDNA fragment to verify equal application of RNA to each lane. In some experiments cells were treated with $\mathrm{T}_{3}$ and $10 \mu \mathrm{g} / \mathrm{ml}$ cyclohexamide (Sigma) simultaneously for 0.5 or $12 \mathrm{~h}$, followed by total RNA isolation and Northern analysis.

\section{Nuclear run-on assay}

Sub-confluent HepG2-TR $\alpha 1 \# 1$ cells were treated with or without $100 \mathrm{nM} \mathrm{T}_{3}$ for $24 \mathrm{~h}$. Cells were subsequently washed twice with ice-cold PBS, collected, and centrifuged at $500 \mathrm{~g}$ for $5 \mathrm{~min}$ at $4{ }^{\circ} \mathrm{C}$. The pellet was gently re-suspended in a buffer containing $10 \mathrm{mM}$ Tris-HCl ( $\mathrm{pH} 7 \cdot 4$ ), $10 \mathrm{mM} \mathrm{NaCl}, 3 \mathrm{mM} \mathrm{MgCl} 2$, and 0.5\% Nonidet P-40, allowed to swell and lyse on ice for $10 \mathrm{~min}$. The lysate was re-centrifuged at $500 \mathrm{~g}$, and the resulting nuclear pellet was re-suspended in $100 \mu$ l of labeling buffer containing $20 \mathrm{mM}$ Tris- $\mathrm{HCl}$ ( $\mathrm{pH} 8 \cdot 0$ ), $10 \mathrm{mM} \mathrm{MgCl}_{2}$, $140 \mathrm{mM} \mathrm{KCl}, 14 \mathrm{mM} \beta$-mercaptoethanol, $1 \mathrm{mM} \mathrm{MnCl}{ }_{2}$ and $20 \%$ glycerol. In vitro transcription using the nuclear pellet $(100 \mu \mathrm{l})$ in labeling buffer with $1 \mathrm{mM}$ creatine kinase, $10 \mathrm{mM}$ phosphocreatine, $1 \mathrm{mM} \mathrm{CTP,} \mathrm{ATP,} \mathrm{GTP,}$ and $100 \mu \mathrm{Ci}$ of $\left[\alpha_{-}{ }^{32} \mathrm{P}\right] \mathrm{UTP}$ as described previously (Liao et al. 1995) was performed in a shaking water bath at $30{ }^{\circ} \mathrm{C}$ for $30 \mathrm{~min}$. Equal amounts $(2 \mu \mathrm{g})$ of purified, denatured full-length Tf, human $\beta$-actin, and linearized pGEM-T cDNA were vacuum-transferred onto nylon membranes using a slot blot apparatus (Amersham). The membranes were baked and pre-hybridized as described for Northern blots. The precipitated radiolabeled transcripts $\left(\sim 10^{7}\right.$ c.p.m.) were re-suspended in $2 \mathrm{ml}$ of hybridization buffer containing 50\% formamide, 5X SSC, 2.5X Denhardt's solution, $25 \mathrm{mM}$ sodium phosphate buffer ( $\mathrm{pH}$ 6.5), $0 \cdot 1 \%$ SDS and $250 \mu \mathrm{g} / \mathrm{ml}$ salmon sperm DNA. Hybridization of radiolabeled transcripts to the nylon membranes was carried out at $42{ }^{\circ} \mathrm{C}$ for $72 \mathrm{~h}$. The membranes were then washed with $1 \mathrm{X}$ SSC, $0 \cdot 1 \%$ SDS for $1 \mathrm{~h}$ at $65^{\circ} \mathrm{C}$ before autoradiography for $24 \mathrm{~h}$ at $-80{ }^{\circ} \mathrm{C}$.

\section{Results}

Expression and trans-activation activity of TRa1 in Hep G2 cell lines

To investigate the role of $\mathrm{TR} \alpha 1$ in the regulation of plasma protein genes, we prepared isogenic lines from HepG2 cells that stably express wild-type TR $\alpha 1$ (HepG2TR $\alpha 1$ clones \#1, \#2 and \#3). As a control, HepG2 cells were transfected with the empty vector, yielding a cell line that expresses the Neo protein (HepG2-Neo cells). The expression of TR $\alpha 1$ in HepG2-Neo cells was not detectable in the immunoblot shown in Fig. 1A. However, endogenous levels were faintly observed after longer exposure times (data not shown). Prominent immunoreactive bands, corresponding to $\mathrm{TR} \alpha 1$, were detected in HepG2-TR $\alpha 1 \# 1, \# 2$ and \#3 using the monoclonal antibody C4 (Fig. 1A). This antibody recognizes an epitope at the $\mathrm{COOH}$ terminus of TR $\alpha 1$ and TR $\beta 1$ (Bhat et al. 1995). Quantitation of the intensity of the immunoreactive bands revealed that the abundance of TR $\alpha 1$ protein in HepG2-wt and HepG2-TR $\alpha 1$ cells was $4 \sim 7$ fold higher than that in HepG2-Neo cells.

A Lys-luciferase reporter construct, was used to compare the transcriptional activity of TR $\alpha 1$ in HepG2TR $\alpha 1 \# 1$, \#2 and \#3 to that of the HepG2-Neo cells (Fig. 1B). HepG2-TR $\alpha 1 \# 1$ cells exhibited the highest transactivity, which was increased in a $\mathrm{T}_{3}$-dependent manner. Clones \#2 and \#3 showed more moderate trans-activation of the reporter construct, while the control HepG2-Neo cells exhibited a low level of trans-activity. These results indicate that the level of TR $\alpha 1$ protein expression correlates well with its functional capacity to trans-activate the expression of downstream genes.

Effects of $T_{3}$ on the expression of plasma protein gene in Hep G2-TRa 1 cells

HepG2-TR $\alpha 1 \# 1$ over-expressing cells were chosen for cDNA microarray analysis of plasma protein gene 


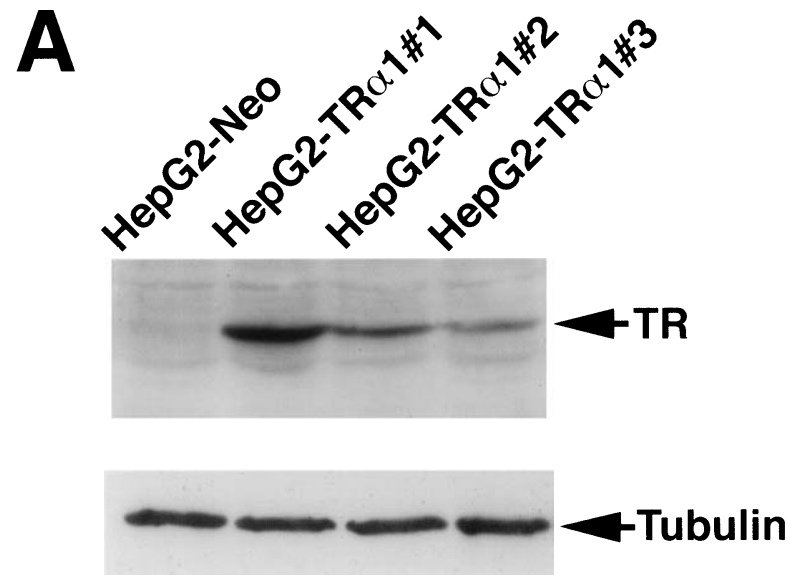

B

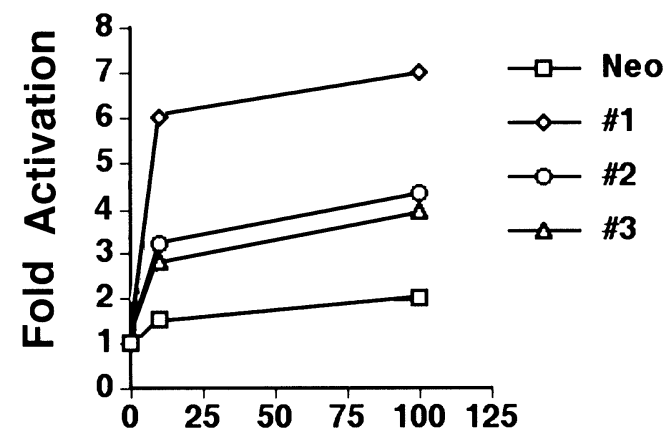

T3 (nM)

Figure 1 Expression and trans-activity of TR $\alpha 1$ in HepG2 cell lines. (A) Immunoblot analysis of the expression of TR $\alpha 1$ in transfected HepG2 cells. Lysates (100 $\mu$ g of protein) of HepG2-TRa1\#1, \#2 and \#3, and HepG2-Neo cells were subjected to immunoblot analysis with monoclonal antibody C4 (Bhat et al. 1995) as described in Materials and Methods. The position of the $47 \mathrm{kDa}$ TR $\alpha 1$ protein is indicated. Tubulin was used as an internal control. (B) $T_{3}$-dependent trans-activity of TRs in the various HepG2 cell lines. Cells were transfected with a luciferase reporter plasmid containing the Lys-TRE, as well as with a $\beta$-galactosidase plasmid to control for transfection efficiency. They were subsequently incubated for $24 \mathrm{~h}$ in $\mathrm{Td}$ medium containing the indicated concentrations of $T_{3}$, after which the activities of luciferase and $\beta$-galactosidase in cell lysates were measured. The activity of luciferase was normalized on the basis of the activity of $\beta$-galactosidase. Data are means \pm S.E. of four independent experiments, each performed in duplicate, and are expressed in light units. The ordinate indicates fold activation and non-induced $=1$.

expression. Time-course treatments with $\mathrm{T}_{3}$ were analyzed at the 3,12, 24 and 48 h stages and the results of the genes that displayed a greater than twofold modulation of expression are shown in Table 1 . At the $48 \mathrm{~h}$ time point, the expression of 20 plasma protein genes was stimulated while five were repressed. Interestingly, four of these 25 genes are involved in blood coagulation while ten others function in inflammation. The expression of albumin and antitrypsin was not affected by $\mathrm{T}_{3}$. Due to the medical significance of iron homeostasis and the lack of previous studies, the Tf gene was chosen for further analysis. Moreover, other up-regulated genes were also chosen for investigation in a separate study.

\section{Effects of $T_{3}$ on the abundance of Tf $m R N A$ and protein in} Hep $\mathrm{G} 2$ cell lines

The expression of the Tf protein $(80 \mathrm{kDa})$ was compared between the various HepG2 cell lines after incubation in media containing various levels of $\mathrm{T}_{3}$ across different time points (Fig. 2). Immunoblot analysis revealed that the exposure of the control HepG2-Neo cells to $100 \mathrm{nM} \mathrm{T}_{3}$ resulted in a slight increase of Tf protein (see Fig. $2 \mathrm{~A}$ and quantitated data in Fig. $2 \mathrm{~B}$ ). $\mathrm{T}_{3}$ significantly increased the abundance of $\mathrm{Tf}$ in the HepG2-TR $\alpha 1$ stable cell lines. The amount of Tf increased approximately $1.5 \sim 2 \cdot 5$-fold after incubation of HepG2-TR $\alpha 1 \# 1, \# 2$ and \#3 cells with $10 \mathrm{nM} \mathrm{T}_{3}$ for $24 \mathrm{~h}$. A slightly greater but significant $(2 \cdot 1-2 \cdot 7$-fold $)$ induction of $\mathrm{Tf}$ was observed when cells were incubated with $100 \mathrm{nM} \mathrm{T}_{3}$ for $24 \mathrm{~h}$. The $\mathrm{T}_{3}$ induction increased further $(\sim 3$ - to $\sim 5$-fold) after $48 \mathrm{~h}$ incubation. These results indicate that the effect of $\mathrm{T}_{3}$ in TR $\alpha 1$ over-expressing cells was time and dose dependent. Thus, the extent of induction for Tf protein expression by $\mathrm{T}_{3}$ correlated with the level of expression of TR $\alpha 1$. Interestingly, the abundance of $\mathrm{Tf}$ protein did not significantly differ among the three TR $\alpha 1$-overexpressed cell lines in the absence of $\mathrm{T}_{3}$ and may, in fact, be silenced (compare all lanes at $0 \mathrm{nM} \mathrm{T}_{3}$ in Fig. 2A).

The effect of $\mathrm{T}_{3}$ on the abundance of $\mathrm{Tf} \mathrm{mRNA}$ was also examined by Northern blot analysis. A $2.3 \mathrm{~kb}$ Tf transcript was detected in all four cell lines examined (Fig. $3 \mathrm{~A})$. Exposure of HepG2-TR $\alpha 1 \# 1, \# 2$ and \#3 cells to $100 \mathrm{nM} \mathrm{T}_{3}$ for $24 \mathrm{~h}$ resulted in a TR $\alpha 1$ dose-dependent and significant increase in the amount of $T f \mathrm{mRNA}$, with increases of $3 \cdot 8-, 2 \cdot 6$ - and $2 \cdot 5$-fold respectively. $\mathrm{T}_{3}$ had little effect on the abundance of $T f$ mRNA in HepG2Neo cells (Fig. 3A). Incubation of HepG2-TR $\alpha 1$ stably transfected cells with $\mathrm{T}_{3}$ at $10 \mathrm{nM}$ also increased the amount of $\mathrm{Tf}$ transcript levels similar to those when using $100 \mathrm{nM} \mathrm{T}_{3}$. This indicates that Tf gene expression is very sensitive to the presence of small amounts of $\mathrm{T}_{3}$ in the medium. In the absence of $\mathrm{T}_{3}$ the abundance of $T f \mathrm{mRNA}$ varied among the cell lines used in this study. Interestingly, it was higher in the Neo cells and this may be due to the silencing effect observed in the TR over-expressed cells (Figs 2 and 3). Thus, the effect of $T_{3}$ on the expression of $\mathrm{Tf}$ protein appears to be mediated, at least in part, at the mRNA level.

\section{$T_{3}$ increases $T f m R N A$ by transcriptional stimulation}

To further confirm the transcription level changes of $T f$ mRNA in response to $T_{3}$, we performed nuclear run-on 
Table $1 \mathrm{~T}_{3}$-regulated plasma protein genes in HepG2-TR cells

\begin{tabular}{|c|c|c|c|c|c|c|}
\hline & & & Time & & & \\
\hline & Molecular function & numbe & $3 \mathrm{~h}$ & $12 \mathrm{~h}$ & $24 \mathrm{~h}$ & $48 \mathrm{~h}$ \\
\hline Genes & & & & & & \\
\hline Orosomucoid 1 & $\begin{array}{l}\text { Acute-phase protein/cardiovascular } \\
\text { function }\end{array}$ & AA700876 & $0 \cdot 96$ & $2 \cdot 40$ & $3 \cdot 87$ & 28.97 \\
\hline Fibrinogen, A $\alpha$ polypeptide & Coagulation & AA011414 & $1 \cdot 66$ & $8 \cdot 07$ & $8 \cdot 84$ & $18 \cdot 20$ \\
\hline Coagulation factor II (thrombin) & Coagulation & H65052 & $2 \cdot 03$ & $3 \cdot 94$ & $6 \cdot 54$ & $12 \cdot 80$ \\
\hline Prothrombin precursor & Coagulation & T62131 & $1 \cdot 50$ & $3 \cdot 47$ & $5 \cdot 14$ & $11 \cdot 15$ \\
\hline Natural killer cells protein 4 & Inflammation & AA458965 & $2 \cdot 67$ & $4 \cdot 73$ & $10 \cdot 50$ & $8 \cdot 71$ \\
\hline Haptoglobin & Inflammation & Al985788 & $0 \cdot 83$ & $0 \cdot 77$ & $4 \cdot 02$ & $8 \cdot 31$ \\
\hline Complement component 1 , s subcomponent & Inflammation & T62048 & $1 \cdot 07$ & $2 \cdot 21$ & $3 \cdot 87$ & $7 \cdot 60$ \\
\hline$\alpha$ 1-microglobulin/bikunin precursor & Inflammation & Al375135 & $1 \cdot 02$ & $1 \cdot 70$ & $3 \cdot 69$ & $7 \cdot 59$ \\
\hline Interleukin 12A (natural killer cell stimulatory factor 1 ) & Inflammation & Al803560 & $1 \cdot 69$ & $3 \cdot 05$ & $4 \cdot 20$ & $6 \cdot 63$ \\
\hline$\beta$ 2-microglobulin & Inflammation & AA670408 & $1 \cdot 01$ & $1 \cdot 11$ & $1 \cdot 53$ & $6 \cdot 59$ \\
\hline Serum amyloid A protein precursor & Inflammation & $\mathrm{H} 25546$ & $1 \cdot 45$ & $2 \cdot 35$ & $1 \cdot 67$ & $6 \cdot 23$ \\
\hline Coagulation factor $X$ & Coagulation & N98524 & $0 \cdot 80$ & $1 \cdot 47$ & $2 \cdot 94$ & $5 \cdot 91$ \\
\hline$\alpha$ 2-HS-glycoprotein $\alpha$ and $\beta$ chain & Inflammation/immune response & R92227 & $0 \cdot 96$ & $2 \cdot 86$ & $4 \cdot 08$ & $5 \cdot 31$ \\
\hline$\alpha$ 2-HS-glycoprotein & Inflammation/immune response & T59108 & $1 \cdot 05$ & $2 \cdot 49$ & $4 \cdot 09$ & $4 \cdot 51$ \\
\hline Complement component $4 \mathrm{~A}$ & Inflammation/immune response & AA664406 & $0 \cdot 94$ & $1 \cdot 53$ & $3 \cdot 34$ & $4 \cdot 35$ \\
\hline Apolipoprotein $\mathrm{Cl}$ & Metabolism/lipid & AA873159 & $12 \cdot 47$ & $26 \cdot 79$ & $26 \cdot 14$ & $4 \cdot 06$ \\
\hline Apolipoprotein CIII & Metabolism/lipid & N53169 & $1 \cdot 51$ & $3 \cdot 53$ & $4 \cdot 12$ & $3 \cdot 54$ \\
\hline Apolipoprotein CII & Metabolism/lipid & AA456474 & $1 \cdot 82$ & $3 \cdot 19$ & $4 \cdot 94$ & $2 \cdot 80$ \\
\hline Angiotensinogen & Blood pressure regulation & Al359985 & $4 \cdot 47$ & $4 \cdot 67$ & $7 \cdot 94$ & $2 \cdot 11$ \\
\hline Transferrin & Transporter/binding protein/iron & H69531 & $3 \cdot 66$ & $5 \cdot 21$ & $6 \cdot 82$ & $2 \cdot 07$ \\
\hline Clusterin & Transporter & AA292226 & $0 \cdot 74$ & $0 \cdot 53$ & $0 \cdot 40$ & $0 \cdot 22$ \\
\hline$\alpha$ 2-macroglobulin precursor & Inflammation/tissue remodeling & AA775447 & $0 \cdot 82$ & $0 \cdot 55$ & $0 \cdot 38$ & $0 \cdot 18$ \\
\hline$\alpha$-fetoprotein & Cell matrix protein & T59043 & $0 \cdot 84$ & $0 \cdot 52$ & $0 \cdot 28$ & $0 \cdot 15$ \\
\hline Human $\alpha$ 2-macroglobulin & Inflammation/tissue remodeling & H06571 & $0 \cdot 43$ & $0 \cdot 36$ & $0 \cdot 29$ & $0 \cdot 14$ \\
\hline Insulin-like growth factor-binding protein-2 & Binding protein & H79047 & $0 \cdot 61$ & $0 \cdot 34$ & $0 \cdot 12$ & $0 \cdot 05$ \\
\hline
\end{tabular}

Genes with a greater than twofold increase or decrease are shown. The data represent the mean of three independent experiments.

The cells were treated with or without $100 \mathrm{nM} \mathrm{T}_{3}$ for the indicated time. Thereafter, RNA was isolated and cDNA microarray was performed as described in the Materials and Methods.

experiments. In parallel with the results of Western and Northern blots, $\mathrm{T}_{3}$ induced approximately a twofold increase in Tf mRNA transcription (Fig. 4). The expression levels of $\beta$-actin were used as an internal control, and pGEM-T vector as a negative control. The data clearly demonstrate that activation of TR, in the presence of $\mathrm{T}_{3}$, can specifically increase the number of $T f$ transcripts engaged in active synthesis by polymerase II machinery, either through enhancement of transcript initiation or that of re-initiation.

Effects of $T_{3}$ and cyclohexamide on the abundance of Tf $m R N A$

In an effort to further delineate the regulatory action of $\mathrm{T}_{3}$ on the expression of $\mathrm{Tf}$, a protein synthesis inhibitor, cyclohexamide, was employed. Tf expression was induced via $T_{3}$, in the presence or absence of cyclohexamide simultaneously for $24 \mathrm{~h}$ in HepG2-TR $\alpha 1 \# 1$ cells. Blocking of protein induction, via cyclohexamide addition, did not greatly affect the transcriptional response of Tf to $\mathrm{T}_{3}$. The two other cell lines highly expressing TR $\alpha 1$ (\#2 and \#3) showed similar results (Fig. 5). Blocking of protein synthesis with the addition of cyclohexamide at various time points $(6-24 \mathrm{~h})$ did not ablate the $\mathrm{T}_{3}$-transcriptional response of Tf (Fig. 6). This suggests that blocking protein synthesis does not completely inhibit the concomitant induction of Tf mRNA by $\mathrm{T}_{3}$. This indicates that the effect of $\mathrm{T}_{3}$ on the regulation of $\mathrm{Tf}$ is direct, rather than via the $\mathrm{T}_{3}$-mediated induction of other messengers.

\section{Discussion}

With the use of HepG2 cells, and the derived stable cell lines, HepG2-TR $\alpha 1$, we have shown that expression of many plasma proteins is modulated by $\mathrm{T}_{3}$. The differential expression of $\mathrm{TR} \alpha 1$ seen in these cell lines revealed that the positive regulation of several plasma proteins, including Tf, by $\mathrm{T}_{3}$ depended on the level of TR $\alpha 1$ expression. It has been long recognized that liver is a target organ for TRs. In fact, Chamba et al. (1996) reported that the abundance of TR $\alpha 1$ and TR $\beta 1$ in normal human liver is 0.8 vs 1.08 absorbance units by Western blot analysis. Their results revealed abundant TR $\alpha 1, \operatorname{TR} \alpha 2$ and TR $\beta 1$ protein in human hepatocyte. Macchia et al. (1990) also 


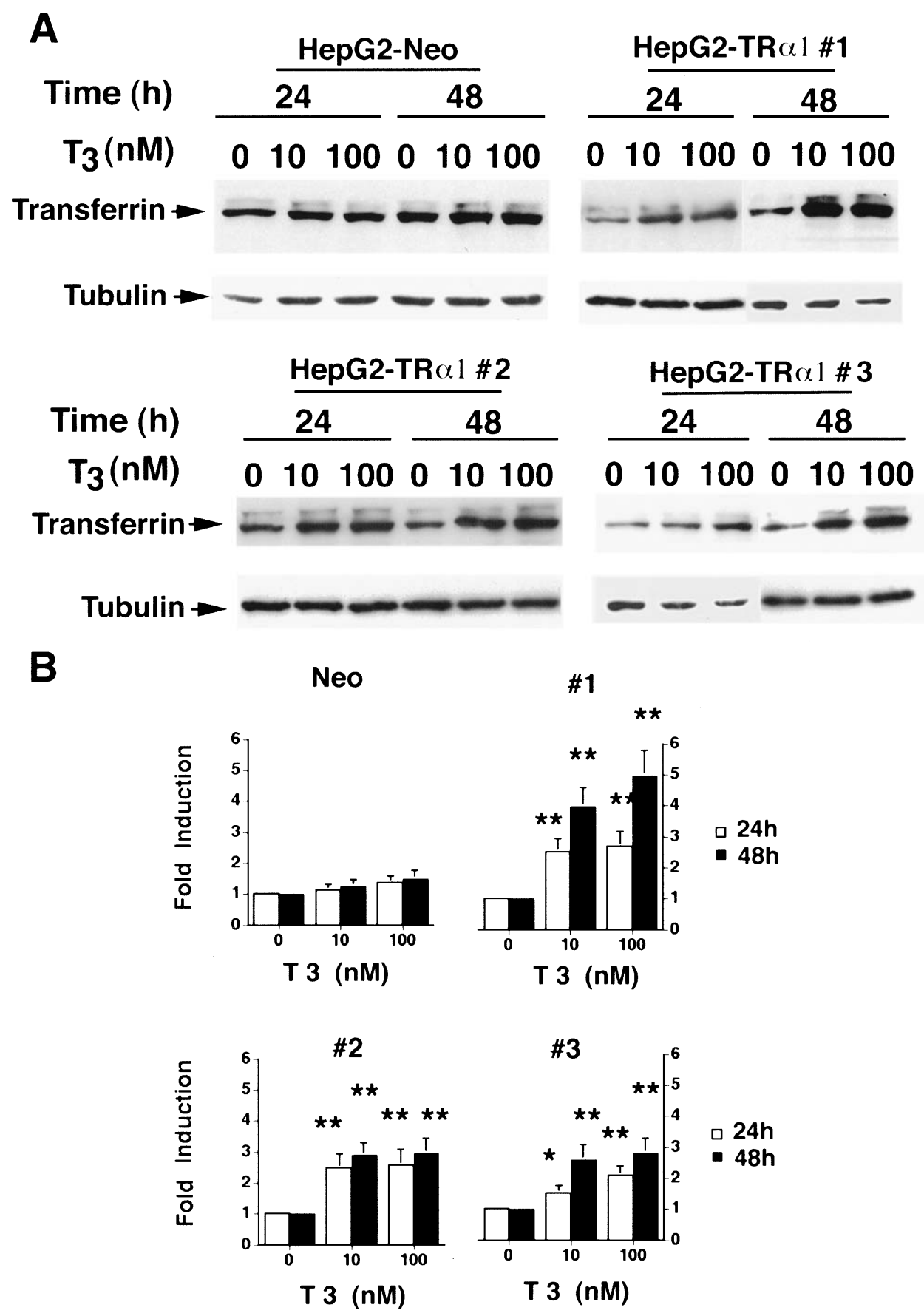

Figure 2 Effect of $\mathrm{T}_{3}$ on Tf protein expression in HepG2 cell lines. (A) HepG2-Neo and HepG2-TR 1 cells were incubated with Td medium in the absence or presence of $100 \mathrm{nM} \mathrm{T}_{3}$ for 1 or 2 days, after which cell lysates $(50 \mu \mathrm{g}$ of protein) were subjected to immunoblot analysis with polyclonal antibodies to Tf. The position of the $80 \mathrm{kDa}$ Tf protein is indicated. (B) The intensities of Tf bands on immunoblots shown in (A) were quantified, and the extent of $\mathrm{T}_{3}$-induced activation of $\mathrm{Tf}$ expression was determined at each time point. Data are means \pm S.E. of values from three independent experiments. Values are shown as fold of induction of Td control. Student's $t$-test; ${ }^{*} P<0 \cdot 05,{ }^{*} P<0 \cdot 01, \mathrm{~T}_{3}-$ vs $\mathrm{Td}$-treated. 


\section{A \\ Neo \#3 \#1 \#2 \\ T3 (nM) 010100010100010100010100 \\ Transferrin $\rightarrow 0 \mathrm{Cec}=0 \mathrm{CO}$}

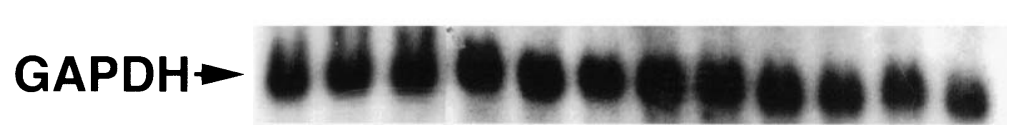

B

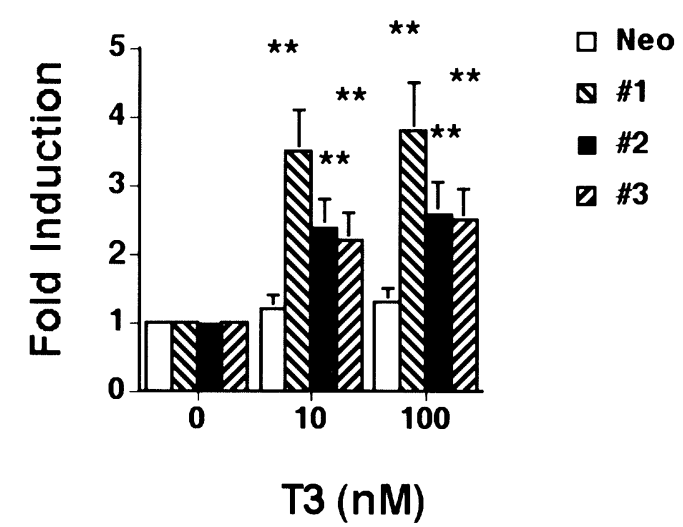

Figure 3 Effect of $T_{3}$ on the abundance of Tf mRNA in HepG2 cell lines. (A) HepG2-TR $\alpha 1$ or HepG2-Neo cells were incubated for $24 \mathrm{~h}$ in the absence or presence of $\mathrm{T}_{3}$, after which total RNA was isolated and subjected ( $20 \mu \mathrm{g}$ per lane) to Northern blot analysis with ${ }^{32} \mathrm{P}$-labeled Tf or GAPDH cDNA probes. The positions of the $2 \cdot 3 \mathrm{~kb}$ Tf and $1.0 \mathrm{~kb}$ GAPDH mRNAs are indicated. (B) The intensities of the Tf mRNA bands shown in (A) were quantified, and the extent of the $T_{3}$-induced increase in the abundance of Tf transcripts was determined at each point. Data are means \pm S.E. of values from three independent experiments. Student's $t$-test; ${ }^{*} P<0 \cdot 01, T_{3}$ - vs Td-treated.

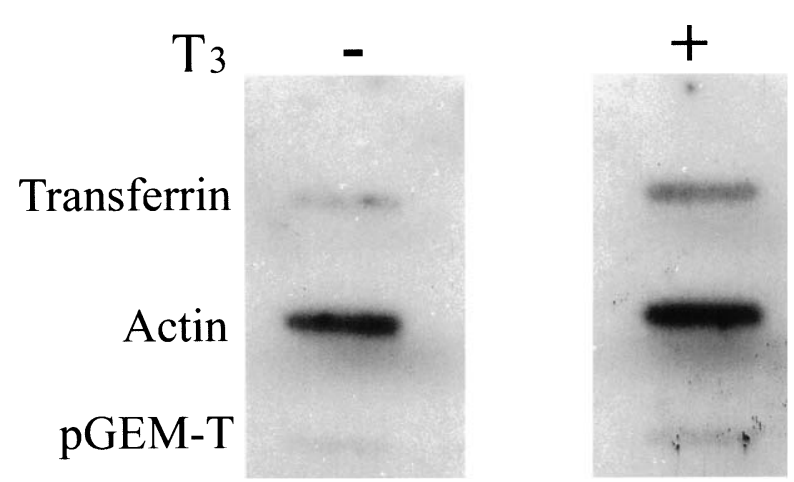

Figure 4 Effect of $\mathrm{T}_{3}$ on $T f$ gene transcription rate, measured in nuclear run-on assay from HepG2-TR 1 cells. Nuclei were isolated after cells were treated with or without $100 \mathrm{nM} \mathrm{T}_{3}$ for $24 \mathrm{~h}$. In vitro transcription using the nuclear pellet labeling with $[\alpha-32$ P]UTP. Total labeled nascent RNA was labeled as described in Materials and Methods and probed against denatured linear plasmids containing the cDNAs indicated at the left of the Figure. Actin and pGEM-T were used as internal controls. reported equal intensity of $47 \mathrm{kDa}(\mathrm{TR} \alpha 1)$ and $55 \mathrm{kDa}$ (TR $\beta 1)$ protein bands from rat liver (Macchia et al. 1990). Moreover, Flores-Morales et al. (2002) used TH $\beta 1$-deficient mice and cDNA microarray to determine the target genes regulated by $T_{3}$. They observed that $T_{3}$ activated a large number of genes in the absence of TR $\beta 1$, suggesting the involvement of TR $\alpha 1$. They further suggested that TR $\alpha 1$ may, in TR $\beta 1(-/-)$ mice, substitute for the absent receptor. All these studies indicate the important but neglected contribution of TR $\alpha 1$ in liver. Therefore, TR $\alpha 1$ must play some important roles not recognized previously.

As well as the role played by $\mathrm{Tf}$ in maintaining serum iron, the iron regulatory protein (IRP) also plays a major role in the regulation of iron homeostasis (Klausner et al. 1993); whereas the regulation of $T f$ by $T_{3}$ was mediated, at least in part, at the transcriptional level, apparently as a result of a direct interaction of TR $\alpha 1$ with the promoter region of this gene. Thus our data indicate that, in the maintenance of iron homeostasis, both transcriptional and translational regulation of related genes may be equally important. 

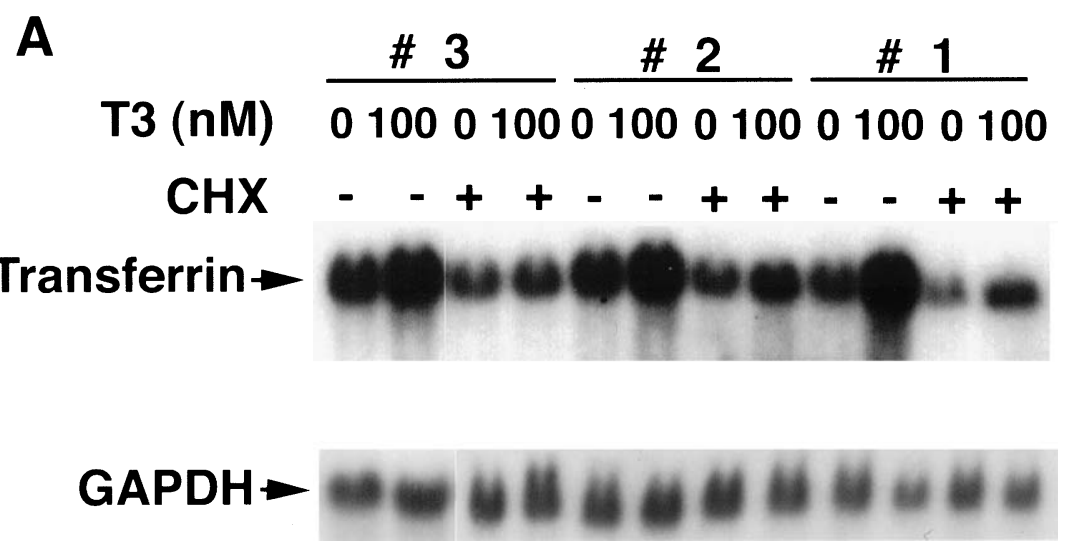

B

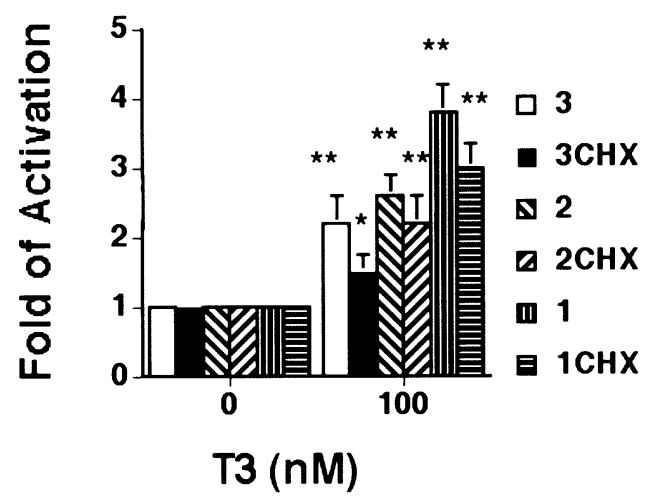

Figure 5 Cyclohexamide $(\mathrm{CHX})$ has a limited effect on the response of $T f$ to $\mathrm{T}_{3}$ activation. (A) HepG2-TR $\alpha 1$ cells were treated as described in Fig. 3 with or without $10 \mu \mathrm{g} / \mathrm{ml}$ cyclohexamide. After $\mathrm{T}_{3}$ activation for $24 \mathrm{~h}$, total RNA was isolated and subjected ( $20 \mu \mathrm{g}$ per lane) to Northern blot analysis. (B) The intensities of the Tf and GAPDH mRNA bands on blots were quantified, and the increase in abundance of $T f$ transcripts was determined at each time point. The data are displayed as a fold induction compared with those in the $\mathrm{Td}$ condition and the data are from three independent experiments. Student's $t$-test; ${ }^{*} P<0 \cdot 05,{ }^{* *} P<0 \cdot 01, T_{3}-$ vs Td-treated.

Several factors have been shown to control the expression of Tf protein. Adrian et al. (Adrian et al. 1986) reported that the $5^{\prime}$ region of the human $T f$ gene contains the heavy metal and glucocorticoid control elements. Their observation was based mainly on the $12 \mathrm{bp}$ sequences in the $\mathrm{Tf} 5^{\prime}$ promoter region that were $\sim 75 \%$ identical to the glucocorticoid receptor response element. In Sertoli cells (Huleihel et al. 2002), interleukin (IL)-1 $\alpha$, $\beta$ and follicle-stimulating hormone (FSH) may induce Tf secretion, and thus may be involved in the regulation of spermatogenesis and spermiogenesis and in male fertility. In addition, interferon- $\gamma$ induced a marked increase in $\mathrm{Tf}$ synthesis by macrophages, while IL-1, IL-6 and tumor necrosis factor- $\alpha$ produced a more modest increase (Barnum-Huckins \& Adrian 2000).

Several groups have reported that $T_{3}$ positively regulates serum ferritin in humans (Macaron \& Macaron
1982, Van de Vyver et al. 1982, Takamatsu et al. 1985, Hashimoto \& Matsubara 1989, Kubota et al. 1993, Barnum-Huckins \& Adrian 2000). Elevated serum ferritin levels were observed in hyperthyroid individuals, and levels decreased significantly after antithyroid treatment which helped to normalize $\mathrm{T}_{3}$ levels (Macaron \& Macaron 1982, Van de Vyver et al. 1982, Takamatsu et al. 1985, Kubota et al. 1993, Barnum-Huckins \& Adrian 2000). Furthermore, administration of $\mathrm{T}_{3}$ to hypothyroid individuals produced a significant increase in the serum ferritin level (Takamatsu et al. 1985, Hashimoto \& Matsubara 1989). Leedman et al. (1996) reported that $\mathrm{T}_{3}$ regulates the Iron response element (IRE) binding activity of the IRP. These links between $T_{3}$ and the regulation of ferritin expression suggest that a positive correlation exists between the levels of thyroxine $\left(\mathrm{T}_{4}\right) / \mathrm{T}_{3}$ and ferritin in the serum. However, the molecular mechanisms involved in 

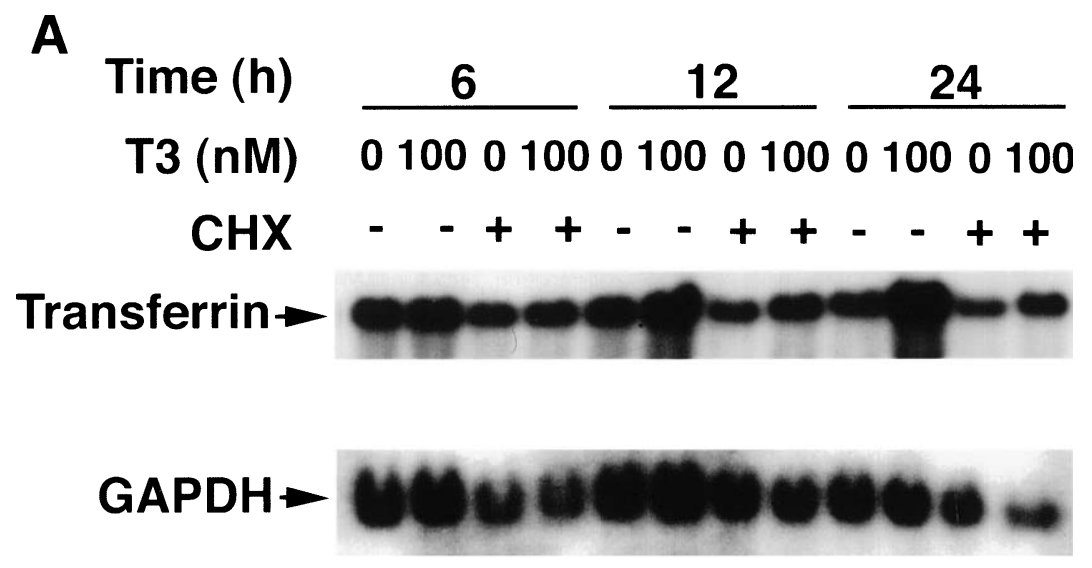

B

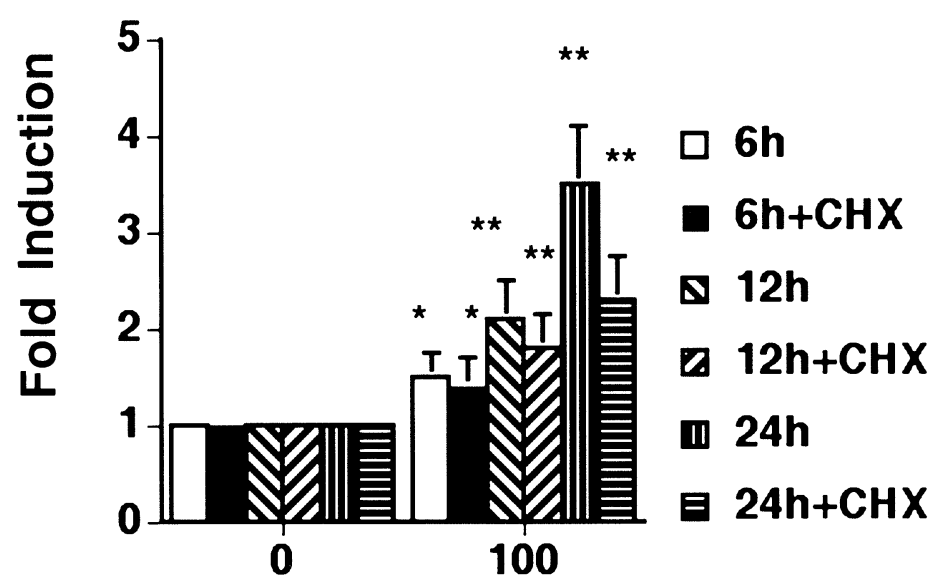

\section{T3 (nM)}

Figure 6 Time-dependent effect of cyclohexamide (CHX) on Tf mRNA expression. (A) HepG2-TR $\alpha 1$ cells were treated as described in Fig. 3 with or without $10 \mu \mathrm{g} / \mathrm{ml}$ cyclohexamide for the indicated time. After $\mathrm{T}_{3}$ activation, total RNA was isolated and subjected (20 $\mu$ g per lane) to Northern blot analysis. (B) The intensities of the $T f$ and GAPDH mRNA bands on blots were quantified, and the increase in abundance of $\mathrm{Tf}$ transcripts was determined at each time point. The data are displayed as a fold induction compared with those in $\mathrm{Td}$ media and the data are from three independent experiments. Student's $t$-test; ${ }^{*} P<0 \cdot 05,{ }^{* *} P<0 \cdot 01, \mathrm{~T}_{3}$ - vs Td-treated.

the hepatic regulation of ferritin expression by $\mathrm{T}_{3}$ had not been determined.

We also studied the regulation of $\mathrm{Tf}$ protein expression by TR $\beta 1$-expressing HepG2 cells (data not shown). However, the extent of $\mathrm{T}_{3}$-induced $\mathrm{Tf}$ expression mediated by TR $\beta 1$ was less than that induced by TR $\alpha 1$. The structures of TR $\alpha 1$ and TR $\beta 1$ differ predominantly in the $\mathrm{A} / \mathrm{B}$ domain and this may be directly involved in the transcriptional regulation of Tf. Moreover, it has been shown that the transcriptional activity of TRs is modulated by a host of co-regulatory proteins (Lin et al. 1994, 1995, 1999, 2001, 2002). Chaudhary \& Skinner (2001) reported that the optimal activation of the mouse $\mathrm{Tf}$ promoter by
FSH requires the synergistic actions of the cAMP response element-binding (CREB) protein and basic helix-loophelix (bHLH) factors. Furthermore, the co-integrator $\mathrm{CBP} / \mathrm{p} 300$ appears to be involved in regulating $\mathrm{FSH}-$ mediated activation of the Tf promoter by linking bHLH and CREB activities.

Recently, cDNA microarray technology has become available (Feng et al. 2000, Flores-Morales et al. 2002) and we have utilized this powerful technique to study the effect of $\mathrm{T}_{3}$ on the expression of hepatic plasma proteins. However, when the livers of $\mathrm{T}_{3}$-treated mice were investigated previously by cDNA microarrays, plasma protein regulation was not discussed (Feng et al. 2000, 
Weitzel et al. 2001, Flores-Morales et al. 2002, Sadow et al. 2003). It is possible that this subset of genes was not represented on the gene-chip or the delayed time course of induction by $\mathrm{T}_{3}$ was not investigated. It is also possible that endogenous TR expression in the liver is not high enough for an effect to be observed. Our data indicate that many plasma proteins including prothrombin, angiotensinogen, haptoglobin, complement, lipoproteins and fibrinogen are up-regulated by $\mathrm{T}_{3}$ at least twofold in a hepatoma cell line that highly expresses TR $\alpha 1$. Thus, further investigation of the regulation of hepatic plasma proteins by $T_{3}$ is required to continue elucidating this important and until now relatively unappreciated mechanism.

Importantly, this study has begun to investigate the molecular effects of $\mathrm{TH}$ on the regulation of plasma proteins. Of particular medical importance are a few of the genes whose expression is modulated in our arrays. For example, human $\alpha 2-\mathrm{HS}$ glycoprotein (AHSG) is involved in important functions such as inhibition of insulin receptor tyrosine kinase activity, inhibition of protease activities and regulation of calcium metabolism and osteogenesis. Mathews et al. (2002) reported that AHSG concentrations start to decrease within a few hours after the onset of acute myocardial infarction (AMI) and return to near normal concentrations during the recovery period (5-7 days after AMI). It is possible that TH may have a role in AMI by regulating the AHSG level.

The genes coding for apolipoprotein AI, CI, CII and CIII produce proteins involved in the transport of cholesterol and other lipids in the plasma and are expressed predominantly in liver and intestine (Rottman et al. 1991). Thus, TH plays an important role in the homeostasis of cholesterol in the vascular endothelium. Taylor et al. (1996) reported that functional positive and negative TH response elements coexist within the rat apolipoprotein AI promoter and both elements contribute to the control of apolipoprotein AI gene expression (Taylor et al. 1996). In our data it is indicated that $\mathrm{TH}$ also positively regulates apolipoprotein CI, CII and CIII. We also observed the above apolipoproteins regulated by $\mathrm{T}_{3}$ (data not shown).

Acute phase amyloid A protein has been reported to be regulated by proinflammatory cytokines and steroid hormones in human aortic smooth muscle cells (Kumon et al. 2002). Lee et al. (2002) reported that haptoglobin gene $(\mathrm{Hp})$ expression is up-regulated by all-trans-retinoic acid in the extrahepatic monocytic cell line, THP-1. Hp is also up-regulated by TH in HepG2 cells (Table 1). $\alpha(1)$-Acid glycoprotein (orosomucoid) is an acute phase protein expressed in most mammalian species and whose concentration raises two- to fivefold during an acute phase reaction (Hochepied et al. 2002). Our results indicate that $\mathrm{TH}$ induces several acute phase inflammatory proteins including orosomucoid, haptoglobin, amyloid A, complement component, AHSG, A1 M and bikunin. Thus, $\mathrm{TH}$ may play an important role in the expression of several serum proteins during blood coagulation or the inflammatory response. Further study is required to dissect the regulatory mechanism by $\mathrm{TH}$ for these genes.

\section{Funding}

This work was supported by grants from Chang-Gung University (CMRP 737, NMRP 092) and the National Science Council of the Republic of China (NSC 872316-B-182-002).

\section{References}

Adrian GS, Korinek BW, Bowman BH \& Yang F 1986 The human transferrin gene: $5^{\prime}$ region contains conserved sequences which match the control elements regulated by heavy metals, glucocorticoids and acute phase reaction. Gene 49 167-175.

Barnum-Huckins K \& Adrian GS 2000 Iron regulation of transferrin synthesis in the human hepatoma cell line HepG2. Cell Biology International 24 71-77.

Bhat MK, McPhie P \& Cheng SY 1995 Interaction of thyroid hormone nuclear receptor with antibody: characterization of the thyroid hormone binding site. Biochemical and Biophysical Research Communications 210 464-471.

Chamba A, Neuberger J, Strain A, Hopkins J, Sheppard MC \& Franklyn JA 1996 Expression and function of thyroid hormone receptor variants in normal and chronically diseased human liver. Journal of Clinical Endocrinology and Metabolism 81 360-367.

Chang C, Lin Y, O-Lee TW, Chou CK, Lee TS, Liu TJ, P'Eng FK, Chen TY \& Hu CP 1983 Induction of plasma protein secretion in a newly established human hepatoma cell line. Molecular and Cellular Biology 3 1133-1137.

Chaudhary J \& Skinner MK 2001 Role of the transcriptional coactivator $\mathrm{CBP} / \mathrm{p} 300$ in linking basic helix-loop-helix and $\mathrm{CREB}$ responses for follicle-stimulating hormone-mediated activation of the transferrin promoter in Sertoli cells. Biology of Reproduction $\mathbf{6 5}$ 568-574.

Cheng SY 2000 Multiple mechanisms for regulation of the transcriptional activity of thyroid hormone receptors. Reviews in Endocrine and Metabolic Disorders 1 9-18.

Eisen MB \& Brown PO 1999 DNA arrays for analysis of gene expression. Methods in Enzymology 303 179-205.

Feelders RA, Kuiper-Kramer EP \& van Eijk HG 1999 Structure, function and clinical significance of transferrin receptors. Clinical and Chemical Laboratory Medicine 37 1-10.

Feng X, Jiang Y, Meltzer P \& Yen PM 2000 Thyroid hormone regulation of hepatic genes in vivo detected by complementary DNA microarray. Molecular Endocrinology 14 947-955.

Flores-Morales A, Gullberg H, Fernandez L, Stahlberg N, Lee NH, Vennstrom B \& Norstedt G 2002 Patterns of liver gene expression governed by TRbeta. Molecular Endocrinology 16 1257-1268.

Hashimoto T \& Matsubara F 1989 Changes in the tumor marker concentration in female patients with hyper-, eu-, and hypothyroidism. Endocrinology Japan 36 873-879.

Hochepied T, Wullaert A, Berger FG, Baumann H, Brouckaert P, Steidler L \& Libert C 2002 Overexpression of alpha(1)-acid glycoprotein in transgenic mice leads to sensitisation to acute colitis. Gut 51 398-404.

Huleihel M, Zeyse D, Lunenfeld E, Zeyse M \& Mazor M 2002 Induction of transferrin secretion in murine Sertoli cells by FSH and IL-1: the possibility of different mechanism(s) of regulation. American Journal of Reproductive Immunology 47 112-117.

Klausner RD, Rouault TA \& Harford JB 1993 Regulating the fate of mRNA: the control of cellular iron metabolism. Cell 72 19-28. 
Kubota K, Tamura J, Kurabayashi H, Shirakura T \& Kobayashi I 1993 Evaluation of increased serum ferritin levels in patients with hyperthyroidism. Clinical Investigation 72 26-29.

Kumon Y, Suehiro T, Faulkes DJ, Hosakawa T, Ikeda Y, Woo P, Sipe JD \& Hashimoto K 2002 Transcriptional regulation of serum amyloid A1 gene expression in human aortic smooth muscle cells involves CCAAT/Enhancer Binding Proteins (C/EBP) and is distinct from HepG2 cells. Scandinavian Journal of Immunology $\mathbf{5 6}$ 504-511.

Kwok JC \& Richardson DR 2002 The iron metabolism of neoplastic cells: alterations that facilitate proliferation? Critical Reviews in Oncology/Hematology 42 65-78.

Lazar MA 1993 Thyroid hormone receptors: multiple forms, multiple possibilities. Endocrine Reviews 14 184-193.

Lee IH, Lee JH, Lee MJ, Lee SY \& Kim IS 2002 Involvement of CCAAT/enhancer-binding protein alpha in haptoglobin gene expression by all-trans-retinoic acid. Biochemical and Biophysical Research Communications 294 956-961.

Leedman PJ, Stein AR, Chin WW \& Rogers JT 1996 Thyroid hormone modulates the interaction between iron regulatory proteins and the ferritin mRNA iron-responsive element. Journal of Biological Chemistry 271 12017-12023.

Liao JK, Zulueta JJ, Yu FS, Peng HB, Cote CG \& Hassoun PM 1995 Regulation of bovine endothelial constitutive nitric oxide synthase by oxygen. Journal of Clinical Investigation 96 2661-2666.

Lin K, Chen S, Zhu XG, Shieh H, McPhie P \& Cheng S 1997 The gene regulating activity of thyroid hormone nuclear receptors is modulated by cell-type specific factors. Biochemical and Biophysical Research Communications 238 280-284.

Lin KH, Lin YW, Parkison C \& Cheng SY 1994 Stimulation of proliferation by $3,3^{\prime}, 5$-triiodo-L-thyronine in poorly differentiated human hepatocarcinoma cells overexpressing beta 1 thyroid hormone receptor. Cancer Letters 85 189-194.

Lin KH, Lin YW, Lee HF, Liu WL, Chen ST, Chang KS \& Cheng SY 1995 Increased invasive activity of human hepatocellular carcinoma cells is associated with an overexpression of thyroid hormone beta 1 nuclear receptor and low expression of the anti-metastatic nm23 gene. Cancer Letters 98 89-95.

Lin KH, Zhu XG, Shieh HY, Hsu HC, Chen ST, McPhie P \& Cheng SY 1996 Identification of naturally occurring dominant negative mutants of thyroid hormone alpha 1 and beta 1 receptors in a human hepatocellular carcinoma cell line. Endocrinology 137 4073-4081.

Lin KH, Shieh HY, Chen SL \& Hsu HC 1999 Expression of mutant thyroid hormone nuclear receptors in human hepatocellular carcinoma cells. Molecular Carcinogenesis 26 53-61.

Lin KH, Shieh HY \& Hsu HC 2000 Negative regulation of the antimetastatic gene Nm23-H1 by thyroid hormone receptors. Endocrinology 141 2540-2547.

Lin $\mathrm{KH}, \mathrm{Wu} \mathrm{YH} \&$ Chen SL 2001 Impaired interaction of mutant thyroid hormone receptors associated with human hepatocellular carcinoma with transcriptional coregulators. Endocrinology 142 653-662.

Lin KH, Wang WJ, Wu YH \& Cheng SY 2002 Activation of antimetastatic Nm23-H1 gene expression by estrogen and its alpha-receptor. Endocrinology 143 467-475.
Macaron CI \& Macaron ZG 1982 Increased serum ferritin levels of hyperthyroidism. Annals of Internal Medicine 96 617-618.

Macchia E, Nakai A, Janiga A, Sakurai A, Fisfalen ME, Gardner P, Soltani K \& DeGroot LJ 1990 Characterization of site-specific polyclonal antibodies to c-erbA peptides recognizing human thyroid hormone receptors alpha 1 , alpha 2 , and beta and native $3,5,3^{\prime}$-triiodothyronine receptor, and study of tissue distribution of the antigen. Endocrinology 126 3232-3239.

Mathews ST, Deutsch DD, Iyer G, Hora N, Pati B, Marsh J \& Grunberger G 2002 Plasma alpha2-HS glycoprotein concentrations in patients with acute myocardial infarction quantified by a modified ELISA. Clinica Chimica Acta 319 27-34.

Rottman JN, Widom RL, Nadal-Ginard B, Mahdavi V \& Karathanasis SK 1991 A retinoic acid-responsive element in the apolipoprotein AI gene distinguishes between two different retinoic acid response pathways. Molecular and Cellular Biology 11 3814-3820.

Sadow PM, Chassande O, Gauthier K, Samarut J, Xu J, O'Malley BW \& Weiss RE 2003 Specificity of thyroid hormone receptor subtype and steroid receptor coactivator-1 on thyroid hormone action. American Journal of Physiology. Endocrinology and Metabolism 284 E36-E46.

Samuels HH, Stanley F \& Casanova J 1979 Depletion of L-3,5,3'triiodothyronine and L-thyroxine in euthyroid calf serum for use in cell culture studies of the action of thyroid hormone. Endocrinology 105 80-85.

Takamatsu J, Majima M, Miki K, Kuma K \& Mozai T 1985 Serum ferritin as a marker of thyroid hormone action on peripheral tissues. Journal of Clinical Endocrinology and Metabolism 61 672-676.

Taylor AH, Wishart P, Lawless DE, Raymond J \& Wong NC 1996 Identification of functional positive and negative thyroid hormoneresponsive elements in the rat apolipoprotein AI promoter. Biochemistry 35 8281-8288.

Theisen M, Behringer RR, Cadd GG, Brinster RL \& McKnight GS 1993 A C/EBP-binding site in the transferrin promoter is essential for expression in the liver but not the brain of transgenic mice. Molecular and Cellular Biology 13 7666-7676.

Van de Vyver FL, Blockx PP, Abs RE, Van den Bogaert WG \& Bekaert JL 1982 Serum ferritin levels in hyperthyroidism. Annals of Internal Medicine 97 930-931.

Weitzel JM, Radtke C \& Seitz HJ 2001 Two thyroid hormonemediated gene expression patterns in vivo identified by cDNA expression arrays in rat. Nucleic Acids Research 29 5148-5155.

Wood WM, Dowding JM, Bright TM, McDermott MT, Haugen BR, Gordon DF \& Ridgway EC 1996 Thyroid hormone receptor beta2 promoter activity in pituitary cells is regulated by Pit-1. Journal of Biological Chemistry 271 24213-24220.

Zhang J \& Lazar MA 2000 The mechanism of action of thyroid hormones. Annual Review of Physiology 62 439-466.

Received 29 May 2003

Accepted 21 August 2003

Made available online as an

Accepted Preprint 28 August 2003 